\title{
USE OF COMPUTATIONAL FLUID DYNAMICS TO SIMULATE TEMPERATURE DISTRIBUTION IN BROILER HOUSES WITH NEGATIVE AND POSITIVE TUNNEL TYPE VENTILATION SYSTEMS
}

\section{USO DE DINÁMICA DE FLUIDOS COMPUTACIONALES PARA SIMULAR LA DISTRIBUCIÓN DE TEMPERATURAS EN GALPONES AVÍCOLAS TIPO TÚNEL CON SISTEMAS DE VENTILACIÓN POSITIVA Y NEGATIVA}

\author{
Jairo Alexander Osorio Saraz ${ }^{1}$, Marcio Arêdes Martins ${ }^{2}$, Keller Sullivan Oliveira Rocha ${ }^{3}$, Neiton Silva Machado ${ }^{4}$, \\ Hector José Ciro Velasques ${ }^{5}$
}

${ }^{1}$ Profesor - Universidad Nacional de Colombia - Sede Medellín, aosorio@unal.edu.co; ${ }^{2}$ Profesor - Universidad Federal de Viçosa - Brazil, aredes@ufv.br ${ }^{3}$ Ingeniero Agrícola, Ph.D. Universidad Federal de Viçosa - Brazil, kellersullivan@yahoo.com. br ${ }^{4}$ Profesor - Universidad Federal del Vale de San Francisco - Brazil, neiton.machado@univasf.edu.br ${ }^{5}$ Profesor - Universidad Nacional de Colombia - Sede Medellín, hjciro@unal.edu.co

Rev. U.D.C.A Act. \& Div. Cient. 16(1): 159 - 166, 2013

\section{SUMMARY}

In tropical and subtropical countries such as Brazil, temperatures inside agricultural facilities reach values greater than those considered suitable for thermal comfort for both animals and people. To predict the behavior and distribution of temperature in all directions of the structure and make correct decisions about the inside environment, the classic research method would require a significant experimental arrangement. Consequently, classic methodologies do not offer immediate information that might predict the internal behavior of the poultry houses against variations of external and internal conditions. The aim of this work was to use and validate the Computational Fluid Dynamics (CFD) as simulation tool to analyze the distribution of temperature in poultry houses with positive or negative pressure tunnel ventilation and with internal misting. The results from numerical simulation correlated well with the experimental data, and it is therefore recommended to predict the thermal behavior inside of poultry house for an animal production tunnel type.

Key words: Computational fluids dynamics (CFD), thermal control, broiler house, thermal comfort.

\section{RESUMEN}

En países tropicales y subtropicales como Brasil, las temperaturas dentro de las instalaciones agrícolas alcanzan valores superiores a los considerados como adecuadas para el confort térmico de los animales y las personas. Para predecir el comportamiento y la distribución de temperatura en todas las direcciones de la estructura y tomar decisiones correctas acerca del control climático en el interior de las instalaciones en tiempo real, al usar los métodos clásicos de investigación se requerirán grandes arreglos experimentales. Por lo tanto, las metodologías clásicas no ofrecen información inmediata que pueda predecir el comportamiento interno de los galpones avícolas contra la variación de las condiciones ambientales externas e internas. El objetivo de este trabajo fue usar y validar la Dinámica de Fluidos Computacional (CFD) como herramienta de simulación para analizar la distribución de la temperatura en los galpones avícolas que trabajan con ventilación de presión positiva o negativa tipo túnel y con sistemas de nebulización interna. Los resultados de la simulación numérica mostraron una buena correlación con los datos experimentales, y que la técnica numérica puede ser usada para predecir el comportamiento térmico en el interior de los galpones avícolas para instalaciones tipo túnel.

Palabras clave: Dinámica de fluidos computacionales (CFD), control térmico, galpones avícolas, confort térmico.

\section{INTRODUCTION}

Brazil is the world largest exporter of poultry, which makes of vital importance that animal welfare laws are fulfilled as 
imposed by the international market. Of the law forming processes relative to animal production, those adopted by the European Community are well advanced. These regulations seek to guarantee animal welfare, which strongly depend on maintenance of temperature levels inside the structures.

Today, the commercial broiler chicken is one of the animals with the greatest performance and speed of development. One of the greatest problems facing the housing of broiler chickens is the elevated indoor temperatures and high concentrations of toxic gases such as ammonia. These accumulations of heat and toxic gasses are the result of architectural and constructive characteristics, which associated with the physical and physiological characteristics of the birds, limit maximum productivity proportional to the animal's genetics. The high variation of Brazil climate (tropical and subtropical) increases the temperatures within the poultry houses during the majority of the year, impairing therefore the performance of the animals.

Temperature and air velocity are considered factors of the greatest influence on the performance of broiler chickens. To evaluate the distribution of these variables along the length of the installation, technical studies were carried out where experimental data are usually measured at the height of the birds at three points (beginning, middle and end) of the building (Curtis,1983). Therefore, distribution of these parameters inside the poultry house upon variation in internal and external physical properties such as temperature, velocity and direction of the wind are unknown.

Understanding of the distribution of these variables can be used to improve thermal comfort of the animals and workers anywhere in the installation, as well as for improving the project in its architectural aspects and in the selection and localization of ventilation equipment. At the same time, this may allow for perfecting the environment in the poultry house, aiming to obtain thermal comfort for the birds economize energy and improve efficiencies. These advantages adequately contribute to animal welfare and environmental sustainability.

In the agriculture sciences the use of CFD models based on heat and mass transfer, as well as momentum ones, have been widely used in several studies to evaluate the effect of some climatic variables to predict the thermal response to inside of plant and animal installations (Ayad, 1999; Wu \& Gebremedhin, 2001; Bjerg et al. 2002; Sun et al. 2002; Aerts \& Berckmans, 2004; Gebremedhin \& Wu, 2005; Norton et al. 2010). These CFD models reduce the number of experiments needed which has aided in achieving higher efficiencies in the agricultural industry.

Some of the advantages of the use of computational models in agriculture sciences, have been presented by Schauberger et al. (2000) as follows: to quantify of the real requirements of ventilation in any part of an installation as function of its occupation; to incorporate external climate conditions for design and selection of ventilation systems; the models can also combine dependent spatial and temporal parameters, which affect distribution of pollutants inside the structure and calculate the concentration of these pollutants as a function of time.

The indoor environment of the poultry houses plays an important role in production performance. Air temperature, relative humidity, pollutant concentration, thermal radiation and air movement can all affect the animal comfort conditions, which reduce bird production as the energy required for their development is used to diminish discomfort based stress. These situations inside the installations can be simulated and analyzed through the use of CFD.

Up to 2007, only three studies on CFD applications in actual scale broiler houses had been published due to computational requirements to solve the equations of the model, an aspect that today has been overcome (Norton et al. 2007).

Based on these facts, the objective of this study was to utilize and validate a computational model for heat transfer and fluid flow based on computational fluid dynamics (CFD) to analyze the temperature distribution at the height of the birds in a acclimatized broiler house with tunnel ventilation systems of negative and positive pressure, with and without internal water misting, which are the most commonly employed types of environmental conditioning systems in Brazilian poultry industry.

\section{MATERIAL AND METHODS}

Operating and experimental conditions: The poultry house analyzed in this study is located in the region of Rio Verde (Goias, Brazil) and is part of the integrated system of the industry. A total of 22700 male Cobb broilers are housed in each installation with a stocking density of 14 birds per $\mathrm{m}^{-2}$. The building dimensions are $126 \mathrm{~m}$ in length, $12.8 \mathrm{~m}$ in width and $3 \mathrm{~m}$ in height at the lateral wall, with $0.5 \mathrm{~m}$ of overhang and $25 \%$ inclination of the roof. The installation presents two lateral air entrances (Figure 1).

The broiler house is non-insulated and is equipped with a mechanical air ventilation system (negative pressure) type tunnel composed of seven exhaust fans with the following characteristics: diameter of $1 \mathrm{~m}, 1 \mathrm{HP}$, efficiency of $76.5 \%$ and air volumetric flow of $22788 \mathrm{~m}^{3} \mathrm{~h}^{-1}$ (air per exhaust fan). A total air flow rate of $159516 \mathrm{~m}^{3} \mathrm{~h}^{-1}$ is produced when all seven exhaust fans are operating, which occurs in the most critical conditions of thermal discomfort (air temperature $>29^{\circ} \mathrm{C}$ ) for broilers with an age greater than 28 days. 


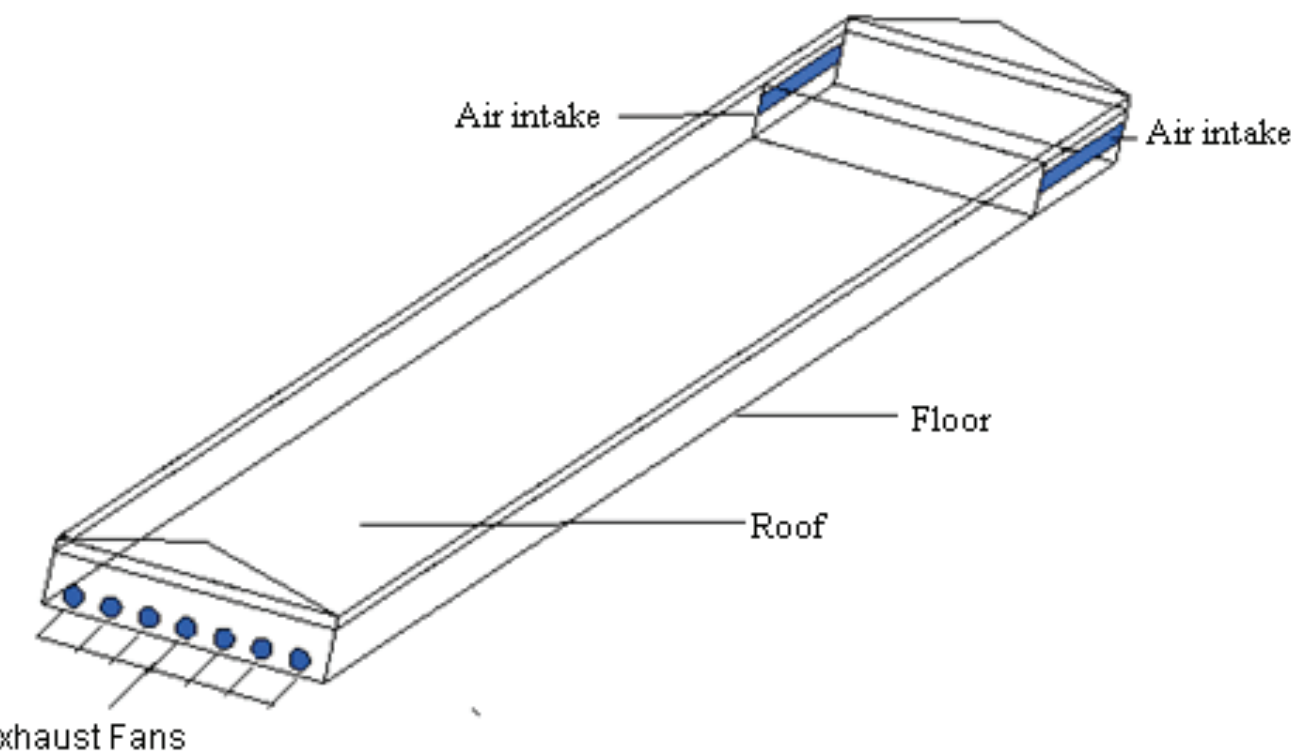

Figure 1. Schematic of the modeled and simulated broiler house

A misting system of the installation is located on the roof $(3 \mathrm{~m})$ and consisted of 180 micro-misters which generated a water flow of $0.25 \mathrm{~m}^{3} \mathrm{~h}^{-1}$ was uniformly distributed throughout the entire building. The misting system was considered in the model as a boundary condition of negative heat transfer and defined by the product of the evaporated water flow by the latent heat of vaporization $\left(\mathrm{h}_{\mathrm{fg}}=2449 \mathrm{~kJ} \mathrm{~kg}^{-1}\right)$ at $29^{\circ} \mathrm{C}$.

The heat transfer generated by the birds was calculated by equation (1) proposed by Curtis (1983) which relates heat transfer to animal body weight. The average body weight used to broiler chicken ranged from 2.4 to $2.8 \mathrm{~kg}$.

$$
Q_{m}=\frac{a W^{b}}{A}
$$

The points of temperature measurement were located $39 \mathrm{~m}$ from the exhaust fans at the height of the birds $(0.30 \mathrm{~m})$ and also near the ceiling ridge $(4.3 \mathrm{~m})$. The values were registered using eight dataloggers of relative humidity and temperature (HOBO model $\mathrm{HO} 8$ ) with resolution of $0.5^{\circ} \mathrm{C}+/-1 \%$, measured at 15 minute intervals. The temperature at the roof was measured with an ICEL infrared thermometer model TD95, with resolution of $1^{\circ} \mathrm{C}$ and accuracy of $+/-2 \%$. Data of the atmospheric environment (temperature, velocity and direction of the wind) were obtained with a data acquisition system installed on a meteorological station $1.5 \mathrm{~m}$ of the ground and in the same direction of the broiler house (eastwest).
Computational modeling: The fluid flows are governed by partial differential equations which represent conservation laws for the mass, momentum, and energy. The CFD was used to solve the Navier - Stokes and energy equations for the computation of velocity, temperature and pressure by the finite volumes technique (Löhner, 2008). Due to the complexity of the geometry, the ANSYS ICEM CFD software was chosen to build a hexagonal computational mesh, which allows for better results with fewer errors than a tetrahedral mesh (Lee et al. 2007).

The physical behavior that characterizes non-isothermal fluid flow is described by means of the equations of continuity, momentum, energy and mass and simplified as follows (Ahmadi \& Hashemabadi, 2008; Kim et al. 2008):

$$
\begin{aligned}
& \frac{\partial \rho}{\partial t}+\nabla \cdot(\rho U)=0 \\
& \frac{\partial(\rho U)}{\partial t}+\nabla \cdot(\rho U U)=\nabla p+\left[\mu_{\tau}\left(\nabla U+\nabla U^{T}\right]\right. \\
& \frac{\partial\left(C_{p} T\right)}{\partial t}+\nabla \cdot\left(-k \nabla T+\rho C_{p} T U\right)=-\frac{d m}{d t} h_{f g} \\
& \frac{\partial C_{i}}{\partial t}+\vec{V} \cdot \nabla C_{i}=\nabla \cdot\left(D \nabla C_{i}\right)+\frac{d m}{d t}
\end{aligned}
$$

The turbulent flow was modeled using the k- $\varepsilon$ standard model, which evaluates the turbulent viscosity $\left(\mu_{\tau}\right)$ from 
the relation between turbulent kinetic energy $(\mathrm{k})$ and the dissipation of the turbulent kinetic energy $(\varepsilon)$.

The term ( $\left.-\frac{d m}{d t} h_{f g}\right)$ in the equation of energy conservation (4) refers to a negative energy that is the defined as the latent heat of vaporization at constant temperature multiplied by the mist flow generated by the spray. Thus, this term is coupled to the equation of energy and species conservation (5).

To the simulation process was employed the ANSYS CFX ${ }^{\circledR}$ under the following conditions: (a) the simulation was initially at steady state followed by transient analysis; (b) incompressible flow; and (c) turbulent flow. A maximal solution residue less than $10^{-4}$ was adapted as convergence criteria to mass, energy and momentum.

Boundary conditions. The measured experimental values in a broiler house with positive pressure tunnel ventilation and internal misting was modeled considering the following boundary conditions: to the inlet the gradient of static pressure $(0 \mathrm{~Pa})$ and air temperature $\left(26^{\circ} \mathrm{C}\right)$; outlet air velocity of $9.95 \mathrm{~m} \mathrm{~s}^{-1}$; ceiling average temperature $\left(55^{\circ} \mathrm{C}\right)$; constant heat flux of $48.7 \mathrm{~W} \mathrm{~m}^{-2}$ to the floor surface.

Validation of the simulation process: The results obtained by the CFD simulation were verified and compared with the corresponding data obtained experimentally in the field for the case of tunnel ventilation with negative pressure. Inside of the poultry house were located eight (8) dataloggers of relative humidity and temperature in different places, at high of level of birds $(0.20 \mathrm{~m})$, and the experimental data was collected during eight (8) days. A total sample of 35 experimental measurements was taken and compared with the CFD results. The model fit between measured values and the numerical result by the CFD simulation was evaluated by calculating the normalized mean square error (NMSE) where values of NMSE less than 0.25 are accepted as good indicators of fit according to ASTM (2002).

$$
N M S E=\frac{\left(\overline{C_{p}-C_{o}}\right)^{2}}{\left(C_{p m} \cdot C_{o m}\right)}
$$

where:

$$
\begin{aligned}
& \left(\overline{C_{p}-C_{o}}\right)^{2}=\frac{\sum_{i}\left(C_{p i}-C_{o i}\right)^{2}}{N} \\
& C_{p m}=\frac{1}{N} \sum_{i} C_{p i} \\
& C_{o m}=\frac{1}{N} \sum_{i} C_{o i}
\end{aligned}
$$

The values of $\mathrm{C}_{\mathrm{pi}}$ and $\mathrm{C}_{\mathrm{oi}}$ are predicted and measured values, respectively. $\mathrm{N}$ is the total number of data.

\section{RESULTS AND DISCUSSION}

The computational mesh for the barn internal air volume was generated using the software ANSYS ICEM CFD. A mesh test was constructed using a quadratic mesh consisting of 127325 nodes and 151218 elements, called mesh 1 . It was compared with a second mesh consisting of 152219 nodes and 189004, called mesh 2, and a third mesh consisting of 157219 nodes and 196994, called mesh 3. It was observed that mesh 2 and mesh 3 showed no significant statistical difference $(p<0.05)$ concerning temperature as function of space and time (Figure 2I and 2II) which makes the mesh 2 the best choice.
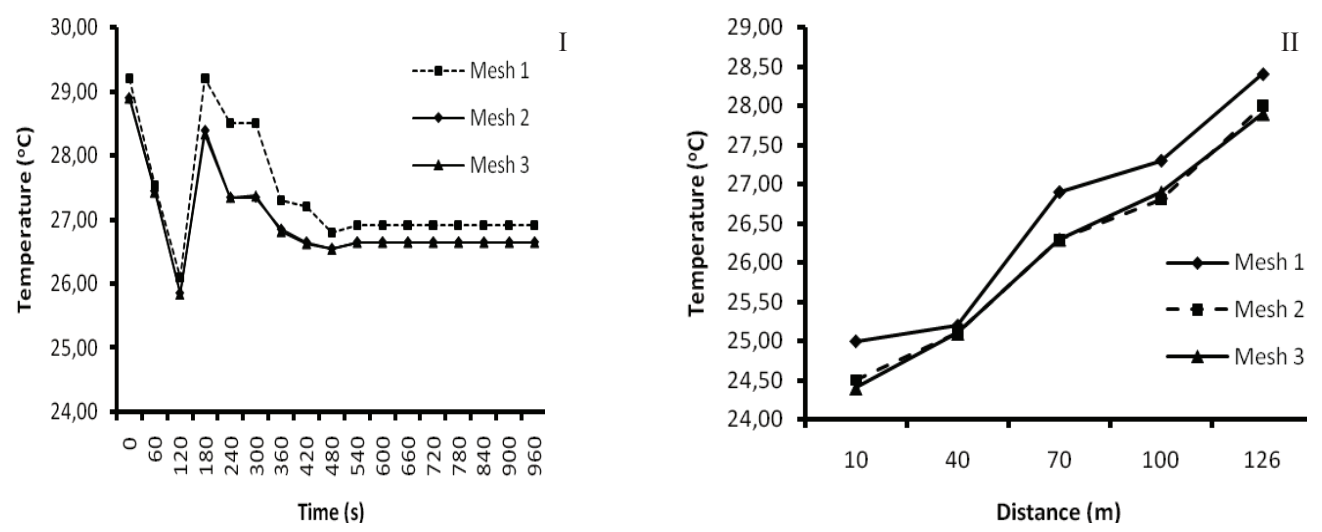

Figure 2. Test for meshes for temporal (I) and spatial (II) distribution. 
Table 1. Experimental data compared with theoretical values found to negative pressure ventilation.

\begin{tabular}{|l|l|c|c|c|}
\hline \multirow{2}{*}{ Data } & \multicolumn{2}{|l|}{ Height of the birds $(\mathbf{0 . 3 0 \mathrm { m } )}$} & \multicolumn{2}{l|}{ Height of the ceiling $(4.3 \mathrm{~m})$} \\
\cline { 2 - 5 } & Experimental $\left({ }^{\circ} \mathrm{C}\right)$ & Proposed model $\left({ }^{\circ} \mathrm{C}\right)$ & Experimental $\left({ }^{\circ} \mathrm{C}\right)$ & Proposed model $\left({ }^{\circ} \mathrm{C}\right)$ \\
\hline Average & 26.49 & 26.76 & 27.74 & 28.25 \\
\hline NMSE & \multicolumn{2}{|c|}{0.0041} & \multicolumn{2}{|c|}{0.0057} \\
\hline
\end{tabular}

For the experimental case where the broiler house work with misting and negative pressure ventilation was used to compare the results of with simulated values of temperature at the level of the birds $(0.30 \mathrm{~m})$ and near the ceiling $(4.3 \mathrm{~m})$. The results indicate that there is no statistical difference (Table 1 ) as the NMSE values were $<0.25$, which indicates that the simulation is capable of accurately predicting temperature under the conditions tested.
Temperature distribution at the birds height level shows a similar behavior to that encountered by Norton et al. (2007). Growing temperature gradients were verified with the proximity to the exhaust fans, with temperatures greater than $30^{\circ} \mathrm{C}$, which causes thermal discomfort of adult broilers ( 6 to 7 weeks of age). The ideal temperature of comfort for broilers at the age of slaughter has been reported to be between 25 and $29^{\circ} \mathrm{C}$.
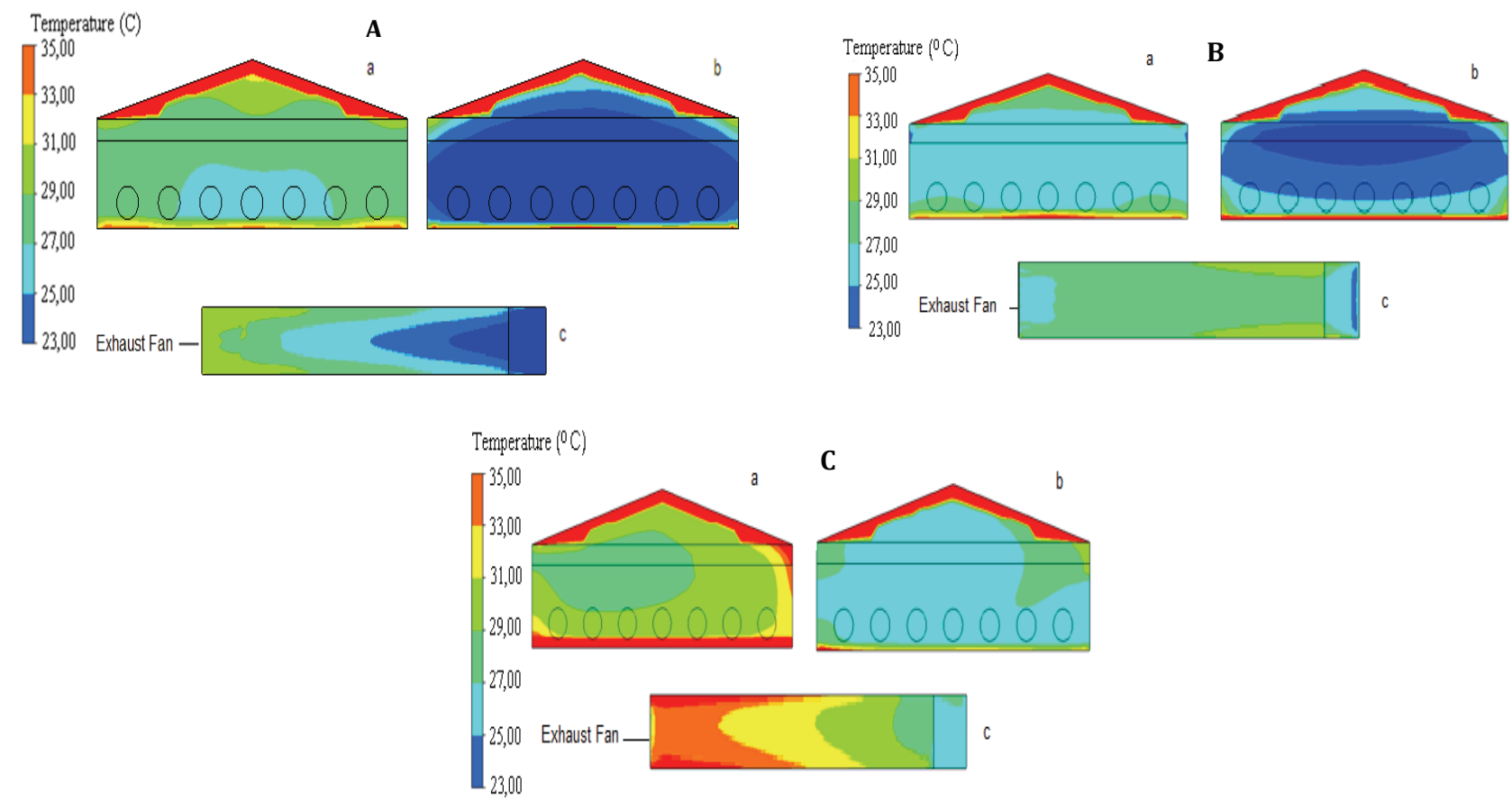

Figure 3. Simulated temperature distribution under different operating conditions: negative pressure ventilation and misting (A); positive pressure ventilation and misting (B); negative pressure ventilation without misting (C) in the central plane (a), lateral entrances (b) and the plane at the height of the birds (c).

Figures $3 \mathrm{~A}, \mathrm{~B}$ and $\mathrm{C}$ present the generated CFD models for air temperature distribution with and without the effect of misting and operating with negative and positive pressure, inside the broiler house at the height of the birds $(0.30 \mathrm{~m})$ and 39 meters from the exhaust fans, where data was collected.
When there are critical operational conditions, such as internal temperatures greater than $29^{\circ} \mathrm{C}$, ventilation systems of negative or positive pressure have been used in combination with adiabatic evaporative cooling systems such as internal misting as analyzed in this work. When both 
systems are used simultaneously (ventilation and misting), temperatures in the range of 23 to $29^{\circ} \mathrm{C}$ are obtained in the big part of the structure (Figure $3 \mathrm{~A}$ ) where it was verified that these temperatures are not uniform throughout the building.

The figure 3B presents the air temperature distributions when using positive pressure ventilation and misting. This condition type is less efficient for reducing air temperature within the structure when compared with negative pressure ventilation. For ventilation with positive pressure, temperature at the bird's height varied between 25 and $33^{\circ} \mathrm{C}$. The lower efficiency of positive pressure ventilation may be explained by the fact that this system generates a low intensity vertical component of velocity which prevents the convective transport of heat generated by the birds. Another consequence of the decrease in air velocity (vertical component) is thermal stratification as the hot air mass near the birds is not mixed with the upper layers where misting occurs (cold air zone).

The difference between the flow dynamics to the positive and negative ventilation cases verified by the proposed simulation, shows that heat removal efficiency is directly related to the vertical air currents. Therefore, favorable situations for the production of these currents are preferred.

Simulation of the installation performance with only the exhaust fans operating and without internal misting shows temperature at the level of the birds varying between 25 and $35^{\circ} \mathrm{C}$, entering in the range of high thermal discomfort. This may be explained by the non-uniformed distribution of temperature throughout the broiler house (Figure 3C).

The distribution of air velocity inside the broiler house with misting and negative pressure ventilation on the plane at the height of the birds shows a behavior similar to the results presented in other studies (Lee et al. 2007; Norton et al. 2007; Blanes-Vidal et al. 2008; Norton et al. 2009). In the regions near the exhaust fans, the rotational flow diminished as expected. According to figure 4 , the air velocity at the height of the birds $(0.3 \mathrm{~m})$ in the plane at the lateral entrances shows velocities between 0 and $2.0 \mathrm{~m} \mathrm{~s}^{-1}$, at the middle of the building between 0 and $1.0 \mathrm{~ms}^{-1}$, and one meter from the exhaust fans from 2.5 to $5.0 \mathrm{~m} \mathrm{~s}^{-1}$. Therefore, it was verified that air velocity values were adequate for boiler chickens (air velocity less than $2.5 \mathrm{~m} \mathrm{~s}^{-1}$ ) values found in real situations.

Figure 5 shows the behavior of temperature versus time at the height of the birds, at 15, 70 and $115 \mathrm{~m}$ from the outlets. It was observed that the steady state temperature in each sector of the poultry house reached values between 500 and 660 seconds, which matches the real operating conditions (experimental data from Figure 5). In reality, as the highest temperature and the longest time of stabilization to reach temperatures in the range of thermal comfort are located close to the exhausters, it is feasible that the temperature sensors which activate the misting cooling and the exhausters be close to the ventilation system.

Based on the obtained results, it was concluded that the proposed CFD simulation can be used to adequately characterize the temperature distribution inside broiler houses. The tested models can be used to improve the design of the structures, placement of air inlets, along with location of the exhaust fans. The evaluation of additional systems, such as misting systems, can also be undertaken with greater precision, allowing for a structure which offers optimal thermal conditions and greater animal performance.

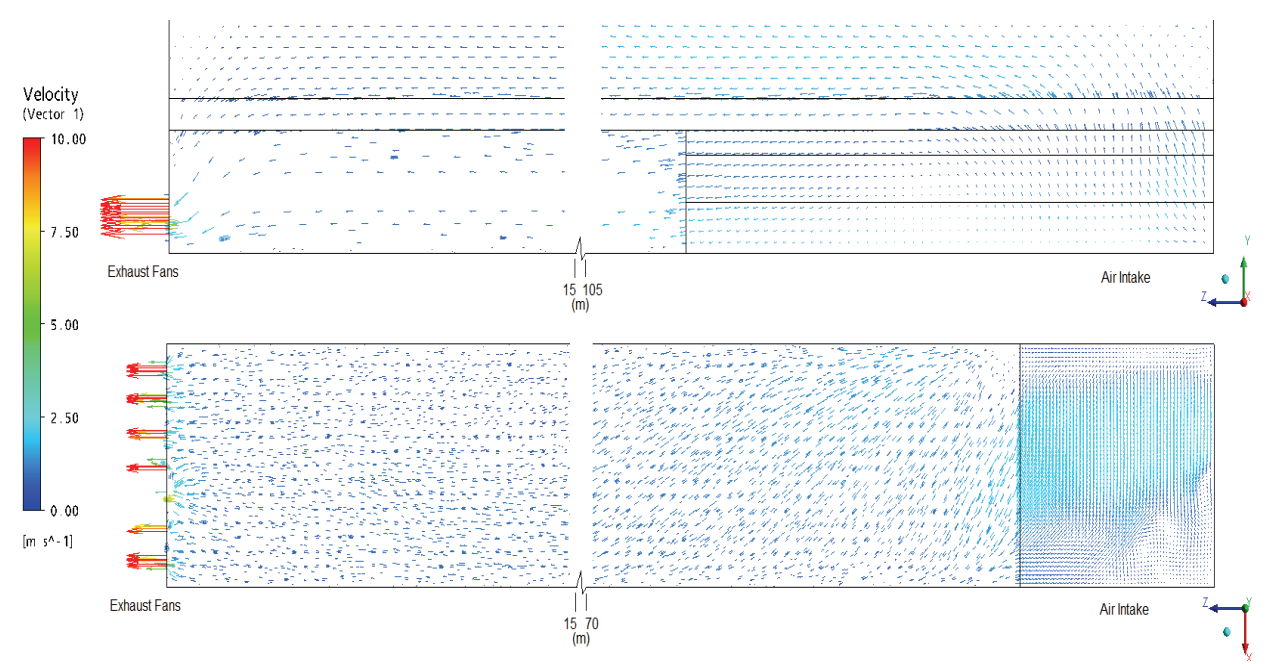

Figure 4. Airflow distribution for negative pressure: a) Transversal section of broiler house; b) $30 \mathrm{~cm}$ above the ground. 


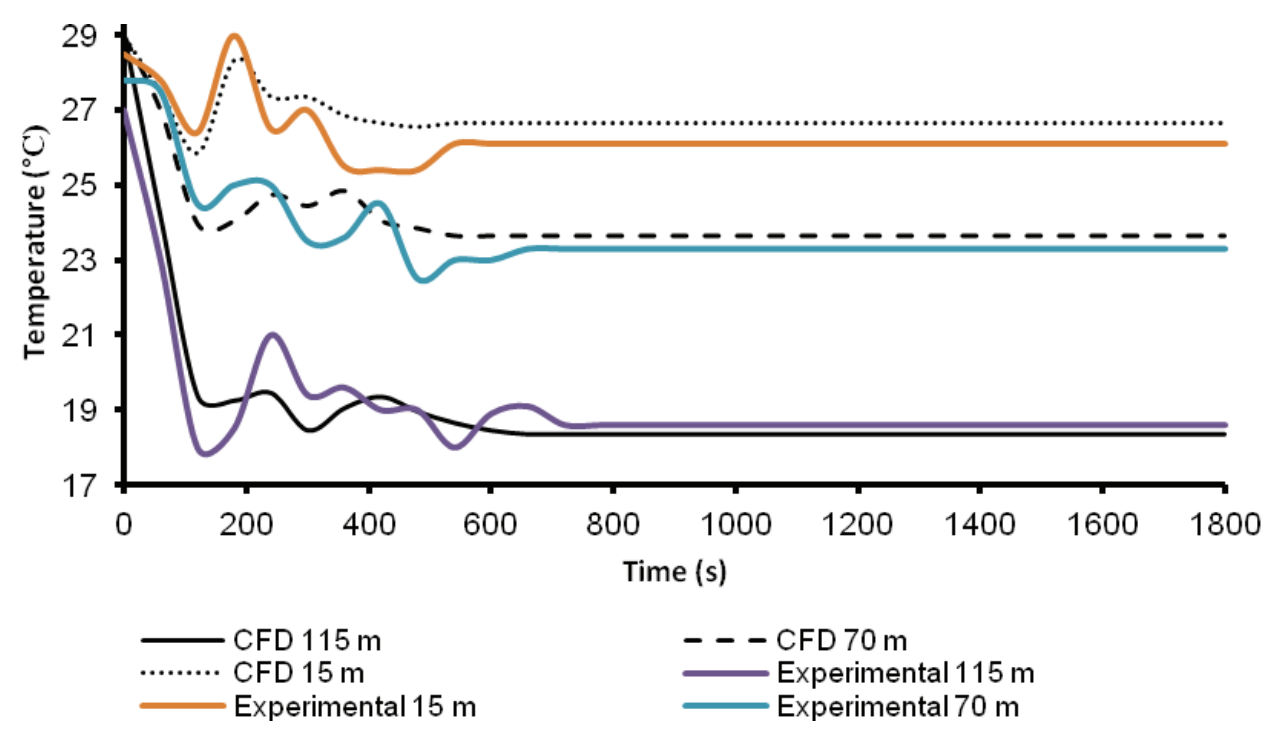

Figure 5. Modeled air temperature for negative pressure at 15, 70 and 115m from exhausters at the bird's height.

\begin{tabular}{|c|c|}
\hline \multicolumn{2}{|c|}{ Nomenclature } \\
\hline$C_{p}$ & Specific heat, $\mathrm{kJ} \mathrm{kg}^{-1} \mathrm{~K}^{-1}$ \\
\hline $\mathrm{C}_{\mathrm{pi}}$ & Predicted value \\
\hline $\mathrm{C}_{\mathrm{oi}}$ & Measured value \\
\hline $\mathrm{C}_{\mathrm{pm}}$ & Average of the predicted values \\
\hline $\mathrm{C}_{\mathrm{om}}$ & Average of the measured values \\
\hline $\mathrm{C}_{\mathrm{i}}$ & Concentration of the species i \\
\hline $\mathrm{h}$ & Convection heat transfer coefficient, $\mathrm{W} \mathrm{m}^{-2} \cdot \mathrm{K}^{-1}$ \\
\hline $\mathrm{h}_{\mathrm{fg}}$ & Latent heat of vaporization, $\mathrm{kJ} \mathrm{kg}^{-1}$ \\
\hline $\mathrm{k}$ & Thermal Conductivity, $\mathrm{W} \mathrm{m}^{-1} \cdot \mathrm{K}^{-1}$ \\
\hline $\mathrm{m}_{\mathrm{p}}$ & Mass of the droplet, $\mathrm{kg}$ \\
\hline$N$ & Number of measurements \\
\hline$Q_{m}$ & Metabolic rate, $\mathrm{kcal} \mathrm{h}^{-1}$ \\
\hline $\mathrm{T}$ & Temperature, K \\
\hline$U$ & Vector velocity \\
\hline$\vec{V}$ & Velocity component, $\mathrm{m} \mathrm{s}^{-1}$ \\
\hline $\begin{array}{l}\mathrm{W} \\
\mathrm{dm} / \mathrm{dt}\end{array}$ & $\begin{array}{l}\text { Average weight of the birds, } \mathrm{kg} \\
\text { Mist flow generated by the spray, } \mathrm{kg} \mathrm{s}^{-1}\end{array}$ \\
\hline \multicolumn{2}{|c|}{ Greek Symbols } \\
\hline $\begin{array}{c}\rho \\
\mu_{\mathrm{t}} \\
\mathrm{k} \\
\varepsilon\end{array}$ & $\begin{array}{l}\text { Density, } \mathrm{kg} \mathrm{m}^{-3} \\
\text { Turbulent Viscosity, Pa.s } \\
\text { Turbulent kinetic energy per unit mass, } \mathrm{J} \mathrm{kg}^{-1} \\
\text { Dissipation rate of } \mathrm{k}, \mathrm{J} \mathrm{kg}^{-1} \mathrm{~s}^{-1}\end{array}$ \\
\hline \multicolumn{2}{|c|}{ Superscripts } \\
\hline $\mathrm{T}$ & Transposition of the tensor \\
\hline \multicolumn{2}{|c|}{ Constants } \\
\hline$a, b$ & Constants equal to 2.9 and 0.75 \\
\hline
\end{tabular}

Acknowledgements: The authors would like to thank the National University of Colombia, Federal University of Viçosa, Minas Gerais State, Brazil, the Colombia Government agency COLCIENCIAS, Brazilian Government agencies FAPEMIG, the National Council of Technological and Scientific Development (CNPq - Brazil) and CAPES, for their financial support. Conflicts of interests: The manuscript was presented and reviewed with the participation of all the authors who declare that there is no conflict of interest that threatens the validity of the results presented.

\section{BIBLIOGRAPHY}

1. AERTS, J.M.; BERCKMANS, D. 2004. A virtual chicken for climate control design: static and dynamic simulations of heat losses. Transact. ASAE. 47(5):1765-1772.

2. AHMADI, A.H.; HASHEMABADI, S.H. 2008. 3D CFD simulation and experimental validation of particleto-fluid heat transfer in a randomly packed bed of cylindrical particles. Int. Communic. Heat Mass Transf. 35(9):1183-1189.

3. ASTM. 2002. Guide for statistical evaluation of indoor air quality models (D5157-97). In ASTM Standards on Indoor Air quality, $2^{\text {nd }}$ ed. Am. Soc. for Testing Materials. West Conshohocken, Pa. p.68-71.

4. AYAD, S.S. 1999. Computational study of natural ventilation. J. Wind Eng. Industrial Aerodyn. 82(1):49-68. 
5. BJERG, B.; SVIDT, K.; ZHANG, G.; MORSING, S.; JOHNSEN, J.O. 2002. Modelling of air inlets in CFD prediction of airflow in ventilated animal houses. Comp. Electron. Agric. 34(1):223-235.

6. BLANES-VIDAL, V.E.; GUIJARRO, S.; BALASCH, E.A.; TORRES, G. 2008. Application of computational fluid dynamics to the prediction of airflow in a mechanically ventilated commercial poultry building. Biosyst. Eng. 100(1):105-116.

7. CURTIS, S.E. 1983. Environmental management in animal agriculture. AMES. The lowa State University. 499p.

8. GEBREMEDHIN, K.G.; WU, B. 2005. Simulation of flow field of a ventilated and occupied animal space with different inlet and outlet conditions. J. Thermal Biol. 30(5):343-353.

9. KIM, K.J.Y.; YOON, H.J.; KWON, J.H.; HAN, J.; EEK SON, S.W.; NAM, G.A.; GIACOMELLI, E.I.; LEE, B. 2008. 3-D CFD analysis of relative humidity distribution in greenhouse with a fog cooling system and refrigerative dehumidifiers. Biosyst. Eng. 100(2):245-255.

10. LÖHNER, R. 2008. Applied Computational Fluid Dynamics Techniques: An Introduction Based on Finite Element Methods ( $2^{\text {nd }}$ ed.). John Wiley \& Sons (England). 538p.

11. LEE, I.B.; SADANOR, S.; SUNG S.H. 2007. Evaluation of CFD Accuracy for the Ventilation Study of a Naturally Ventilated Broiler House. JARQ. 41(1):53-64.
12. NORTON, T.; GRANT, R.J.; FALLON, V., SUN, D.W. 2010. Improving the representation of thermal boundary conditions of livestock during CFD modelling of the indoor environment. Comp. Electron. Agric. 73(1):17-36.

13. NORTON, T.; GRANT, R.J.; FALLON, V., SUN, D.W. 2009. Assessing the ventilation effectiveness of naturally ventilated livestock buildings under wind dominated conditions using computational fluid dynamics. Biosyst. Eng. 103(1):78-99.

14. NORTON, T.; SUN, D.W.; GRANT, R.J.; FALLON, V. 2007. Applications of computational fluid dynamics (CFD) in the modeling and design of ventilation systems in the agricultural industry. A review. Biores. Techn. 98(12):2386-2414.

15. SCHAUBERGER, G.; PIRINGER, M.; PETZ, E. 2000. Steady state balance model to calculate the indoor climate of livestock buildings, demonstrated for finishing pigs. Int. J. Biometeorol. 43(4):154-162.

16. SUN, H.H.; KEENER, R.; STOWELL, R.; MICHEL JR, F.C. 2002. Two-dimensional computational fluid dynamics (CFD) modeling of air and ammonia distribution in a High-RiseTM Hog Building (HRHB). Trans. ASAE. 45(5):1559-1568.

17. WU, B.; GEBREMEDHIN, K.G. 2001. CFD Development and Simulation of Flow Fields in Ventilated Spaces with Multiple Occupants. Transact. ASAE. 44(6):1839-1850.

Received: 17 May 2012

Accepted: 11 March 2013 